\title{
IRON-MANGANESE SYSTEM FOR PREPARATION OF RADIOCARBON AMS TARGETS: CHARACTERIZATION OF PROCEDURAL CHEMICAL-ISOTOPIC BLANKS AND FRACTIONATION
}

\author{
R. MICHAEL VERKOUTEREN, DONNA B. KLINEDINST and LLOYD A. CURRIE
}

Surface and Microanalysis Science Division, National Institute of Standards and Technology Gaithersburg, Maryland 20899 USA

\begin{abstract}
We report a practical system to mass-produce accelerator mass spectrometry (AMS) targets with 10-100 $\mu \mathrm{g}$ carbon samples. Carbon dioxide is reduced quantitatively to graphite on iron fibers via manganese metal, and the $\mathrm{Fe}-\mathrm{C}$ fibers are melted into a bead suitable for AMS. Pretreatment, reduction and melting processes occur in sealed quartz tubes, allowing parallel processing for otherwise time-intensive procedures.

Chemical and isotopic $\left({ }^{13} \mathrm{C},{ }^{14} \mathrm{C}\right)$ blanks, target yields and isotopic fractionation were investigated with respect to levels of sample size, amounts of $\mathrm{Fe}$ and $\mathrm{Mn}$, pretreatment and reduction time, and hydrogen pressure. With 7-day pretreatments, carbon blanks exhibited a lognormal mass distribution of $1.44 \mu \mathrm{g}$ (central mean) with a dispersion of $0.50 \mu \mathrm{g}$ (standard deviation). Reductions of $10 \mu \mathrm{g}$ carbon onto targets were complete in $3-6 \mathrm{~h}$ with all targets, after correction for the blank, reflecting the ${ }^{13} \mathrm{C}$ signature of the starting material. The $100 \mu \mathrm{g}$ carbon samples required at least $15 \mathrm{~h}$ for reduction; shorter durations resulted in isotopic fractionation as a function of chemical yield. The trend in the ${ }^{13} \mathrm{C}$ data suggested the presence of kinetic isotope effects during the reduction. The observed $\mathrm{CO}_{2}$-graphite ${ }^{13} \mathrm{C}$ fractionation factor was $3-4 \%$ smaller than the equilibrium value in the simple Rayleigh model. The presence of hydrogen promoted methane formation in yields up to $25 \%$.

$\mathrm{Fe}-\mathrm{C}$ beaded targets were made from NIST Standard Reference Materials and compared with graphitic standards. Although the ${ }^{12} \mathrm{C}$ ion currents from the beads were one to two orders of magnitude lower than currents from the graphite, measurements of the beaded standards were reproducible and internally consistent. Measurement reproducibility was limited mainly by Poisson counting statistics and blank variability, translating to ${ }^{14} \mathrm{C}$ uncertainties of $5-1 \%$ for $10-100 \mu \mathrm{g}$ carbon samples, respectively. A bias of 5-7\% (relative) was observed between the beaded and graphitic targets, possibly due to variations in sputtering fractionation dependent on sample size, chemical form and beam geometry.
\end{abstract}

\section{INTRODUCTION}

Much interest exists in refining methods for ${ }^{14} \mathrm{C}$ analysis of small samples (Mook 1984; Sellschop 1987; Vogel 1995). Methods currently used for the production of AMS targets are most applicable to carbon samples larger than $100 \mu \mathrm{g}$ (e.g., Polach 1984; Vogel et al. 1984; Jull et al. 1986; Vogel, Nelson and Southon 1987; Slota et al. 1987; Slota and Taylor 1989). Below $100 \mu \mathrm{g}$, catalytically produced graphitic targets become progressively more difficult to mount and have less predictable stabilities and lifetimes in AMS ion sources. Dilution of small samples with $\mathrm{CO}_{2}$ or graphite of known ${ }^{14} \mathrm{C}$ composition has been attempted to extend the sample size range downwards, but this technique suffers from added technical requirements and larger blank uncertainties. ${ }^{14} \mathrm{C}$ analyses are limited in part by mass/isotopic variabilities in the blank, and most laboratories assume a constant addition of modern carbon equivalent (e.g., Kirner, Taylor and Southon 1995; McNichol et al. 1995). This is acceptable for larger, near-modern samples, but inappropriate for smaller samples when procedural blank levels become a significant fraction of the total signal (Currie 1994, 1995). In these cases, mass and isotopic characteristics of the procedural blank are needed for accurate signal corrections. While several promising batch methods have been reported recently for the mass production of small AMS targets (e.g., Wilson 1992; Vogel 1992; Kitagawa et al. 1993), procedural blank levels and variability have been reported as limiting factors.

The method described is based upon the Fe-C beaded target approach (Verkouteren et al. 1987), the targets from which are comparable with those of graphite in beam intensity, stability and longevity (Klinedinst et al. 1994). The major chemical modification is the use of manganese instead of zinc as the reducing agent for $\mathrm{CO}_{2}$. This substitution has allowed the development of an isothermal, closed- 
tube, batch process approach. As a substitute for zinc, manganese is a stronger reducing agent yet not so electropositive as to reduce $\mathrm{CO}$ to elemental carbon. Graphite production requires a reduction temperature of $450-650^{\circ} \mathrm{C}$, and the vapor pressure of manganese (as opposed to zinc) is very low in this temperature range (Desai 1987). This property permits high temperatures for system pretreatment and outgassing of blank carbon without volatilizing the reagents. Packing all necessary reagents into a low-volume closed tube achieves higher system pressures, thereby improving reduction rates (Verkouteren and Klouda 1992). In this system, hydrogen is unnecessary for the reduction.

We designed experiments to explore the feasibility of the $\mathrm{Mn}-\mathrm{Fe}$ reduction system. Reductions were performed only at $500^{\circ} \mathrm{C}$, a temperature below the $600-650^{\circ} \mathrm{C}$ range commonly used for reductions, but which favors low-hydrogen (i.e., low methane by-product) reduction chemistry (Equations 1-6 in Table 1; cf. Olsson and Turkdogan 1974). Chemical and isotopic $\left({ }^{13} \mathrm{C}\right.$ and $\left.{ }^{14} \mathrm{C}\right)$ system blanks and standards were characterized, and sample reductions were quenched at various times to measure changes in chemical and isotopic compositions.

TABLE 1. Chemical Equilibria and Equilibrium Constants* for the Fe-Mn Reduction System

\begin{tabular}{|c|c|c|}
\hline $\begin{array}{c}\text { Equation } \\
\text { no. }\end{array}$ & Chemical equilibria $\dagger$ & $\ln K^{773}$ \\
\hline 1 & $\mathrm{Mn}+\mathrm{H}_{2} \mathrm{O} \rightarrow \mathrm{MnO}+\mathrm{H}_{2}$ & 19.17 \\
\hline 2 & $\mathrm{Mn}+\mathrm{CO}_{2} \rightarrow \mathrm{MnO}+\mathrm{CO}$ & 17.55 \\
\hline 3 & $\mathrm{CO}+\mathrm{CO} \underset{\leftrightarrow}{\stackrel{M}{M} \mathrm{CO}_{2}+\mathrm{C}_{\text {graphite }}}$ & 5.49 \\
\hline 4 & $\mathrm{CO}+\mathrm{H}_{2} \underset{\leftrightarrow}{\mathrm{M}} \mathrm{H}_{2} \mathrm{O}+\mathrm{C}_{\text {graphite }}$ & 3.89 \\
\hline 5 & $\mathrm{CO}+3 \mathrm{H}_{2} \stackrel{\mathrm{M}}{\leftrightarrow} \mathrm{H}_{2} \mathrm{O}+\mathrm{CH}_{4}$ & 4.65 \\
\hline 6 & $\mathrm{C}_{\text {graphite }}+2 \mathrm{H}_{2} \underset{\mathrm{M}}{\stackrel{\mathrm{C}}{\leftrightarrows} \mathrm{C}_{4}}$ & 0.76 \\
\hline
\end{tabular}

\section{METHODS}

\section{Pretreatment}

As illustrated in Figure 1, iron fibers (Fibrex ${ }^{\mathrm{TM}}$, National Standard Co.) ${ }^{1}$ and manganese metal (99.99\%, Johnson Matthey) were placed into annealed quartz tubes (4 mm inner diameter $\times 6 \mathrm{~mm}$ outer diameter, $25 \mathrm{~cm}$ long), then evacuated and sealed with $500 \mathrm{hPa} \mathrm{H}_{2}(99.999 \%)$. The tubes were then heated at $300^{\circ} \mathrm{C}$ for up to $7 \mathrm{~d}$. This treatment fully reduced the iron and hydrogenated some blank carbon for removal. Just before a $\mathrm{CO}_{2}$ sample was introduced, a tube was opened in a cracker, evacuated and torch heated to about $600^{\circ} \mathrm{C}$.

\section{Procedural Blank Characterization}

Twenty tubes, pretreated and containing various amounts of $\mathrm{Fe}, \mathrm{Mn}$ and $\mathrm{H}_{2}$, were sealed without sample (Table 2). Tubes were heated at $500^{\circ} \mathrm{C}$ for $15 \mathrm{~h}$, then cracked open, evacuated, backfilled with helium, and the manganese removed while anchoring the iron with a small magnet. One hun-

\footnotetext{
${ }^{1}$ Certain commercial equipment, instruments, or materials are identified in this paper to specify adequately the experimental procedure. Such identification does not imply recommendation or endorsement by the National Institute of Standards and Technology, nor does it imply that the materials or equipment identified are necessarily the best available for the purpose.
} 


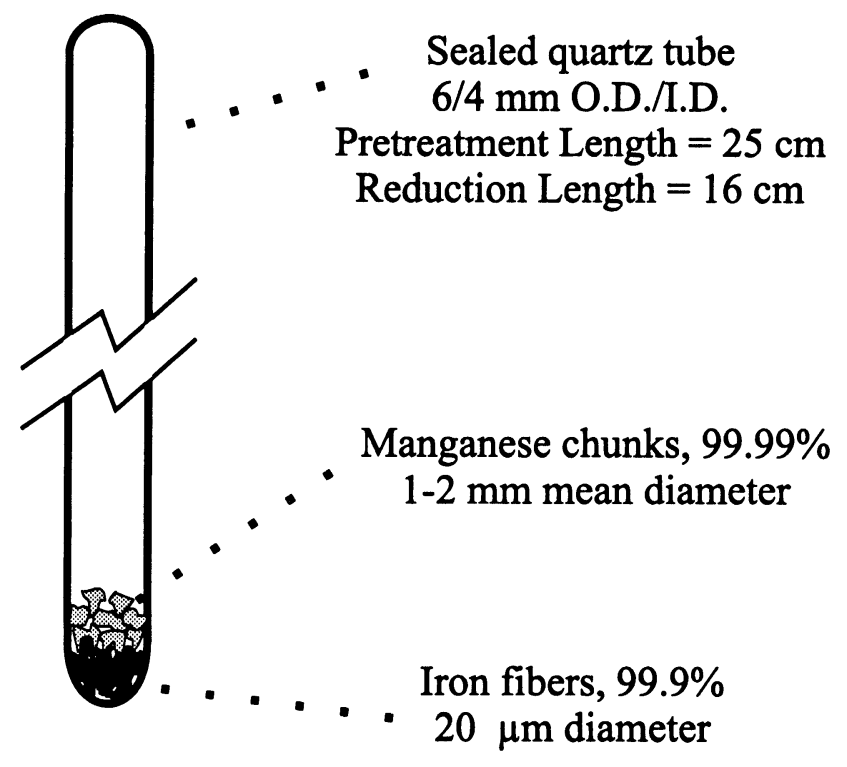

Fig 1. The Fe-Mn chemical reduction system for 10-100 $\mu \mathrm{g}$ carbon samples $\left(\right.$ as $\left.\mathrm{CO}_{2}\right)$. At the end of the reduction, a small magnet was used to anchor the graphitized iron while removing the manganese. The iron was then melted into a bead under helium and mounted as an AMS target.

TABLE 2. Four-Factor Experimental Design and Results of Carbon Blank Study

\begin{tabular}{|c|c|c|c|c|c|c|c|c|}
\hline $\begin{array}{l}\text { Procedural } \\
\text { Blank }\end{array}$ & $\begin{array}{c}\text { Pretreatment } \\
\text { at } 300^{\circ} \mathrm{C} \text { with } \\
0.1 \mathrm{MPa} \mathrm{H} \mathrm{H}_{2} \\
\text { (days) }\end{array}$ & $\begin{array}{c}\mathrm{Fe} \\
(\mathrm{mg})\end{array}$ & $\begin{array}{l}\mathrm{Mn} \\
(\mathrm{mg})\end{array}$ & $\begin{array}{c}\mathrm{H}_{2} \\
\text { in red. } \\
(\mathrm{hPa})\end{array}$ & $\begin{array}{c}\text { Blank } \\
\text { carbon } \\
(\mu \mathrm{g})\end{array}$ & $\begin{array}{c}\text { Blank C } \\
\text { variability }(u) \\
w / r / t \text { level of } \\
\text { pretreatment } \\
(\mu \mathrm{g})\end{array}$ & $\begin{array}{c}\text { Blank C } \\
\text { variability }(u) \\
w / r / t \text { Level of } \\
\text { Mn }(\mu \mathrm{g})\end{array}$ & $\begin{array}{c}\text { Blank } \\
\delta^{13} C_{\mathrm{VPDB}} \\
(\% o)\end{array}$ \\
\hline B1 & 3 & 10.45 & 309.70 & 0 & 3.77 & 1.66 & 1.40 & $-28.0 \pm 0.2$ \\
\hline B2 & 7 & 9.66 & 0.00 & 0 & 1.79 & 0.50 & 0.38 & $-27.2 \pm 0.5$ \\
\hline B3 & 7 & 9.69 & 294.61 & 0 & 0.90 & 0.50 & 1.40 & $-29.6 \pm 0.5$ \\
\hline B4 & 0 & 21.51 & 0.00 & 0 & 2.24 & 1.52 & 0.38 & $-28.6 \pm 0.2$ \\
\hline B5 & 7 & 9.00 & 100.50 & 0 & 1.70 & 0.50 & 0.49 & -- \\
\hline B6 & 7 & 10.32 & 0.00 & 0 & 1.82 & 0.50 & 0.38 & $-27.6 \pm 0.5$ \\
\hline B7 & 3 & 9.84 & 99.19 & 0 & 1.42 & 1.66 & 0.49 & $-28.8 \pm 0.5$ \\
\hline B8 & 1 & 10.00 & 300.73 & 0 & 1.32 & 1.52 & 1.40 & $-29.1 \pm 0.5$ \\
\hline B9 & 0 & 9.20 & 0.00 & 0 & 1.32 & 1.52 & 0.38 & $-28.1 \pm 0.5$ \\
\hline B10 & 7 & 10.12 & 104.93 & 0 & 0.82 & 0.50 & 0.49 & $-30.3 \pm 0.5$ \\
\hline B11 & 7 & 10.66 & 106.92 & 0 & 1.65 & 0.50 & 0.49 & $-28.3 \pm 0.5$ \\
\hline B12 & 7 & 10.15 & 97.99 & 0 & 1.03 & 0.50 & 0.49 & $-30.0 \pm 0.5$ \\
\hline B13 & 7 & 10.00 & 101.50 & 0 & 2.25 & 0.50 & 0.49 & $-28.2 \pm 0.2$ \\
\hline B14 & 7 & 10.24 & 102.55 & 0 & 1.54 & 0.50 & 0.49 & $-30.0 \pm 0.5$ \\
\hline B15 & 7 & 10.24 & 102.23 & 0 & 0.85 & 0.50 & 0.49 & $-31.3 \pm 0.5$ \\
\hline B16 & 0 & 9.20 & 227.50 & 50 & 2.58 & 1.52 & 1.95 & $-26.8 \pm 0.2$ \\
\hline B17 & 0 & 6.10 & 283.09 & 0 & 0.82 & 1.52 & 1.40 & -- \\
\hline B18 & 0.250 & 13.10 & 182.48 & 0 & 0.81 & 1.52 & 1.95 & -- \\
\hline B19 & 0.625 & 10.60 & 171.50 & 50 & 5.46 & 1.52 & 1.95 & $-29.0 \pm 0.1$ \\
\hline B20 & 0.625 & 8.01 & 224.99 & 0 & 2.27 & 1.52 & 1.95 & -- \\
\hline$u_{c}^{*}$ & 0.02 & 0.01 & 0.01 & 1 & 0.02 & -- & -- & above $( \pm)$ \\
\hline
\end{tabular}

*Combined standard uncertainty of measurements (ISO 1993; Taylor and Kuyatt 1994). 
dred milligrams of $\mathrm{CuO}$ wire was added to each tube, then each was evacuated, resealed and heated in a furnace for $6 \mathrm{~h}$ at $900^{\circ} \mathrm{C}$ to produce the procedural blank as $\mathrm{CO}_{2}$. Several cryogenic distillations were performed to remove water; during the first distillation, tubes were heated to $250^{\circ} \mathrm{C}$ for $2 \mathrm{~min}$ with a heat gun to decompose any $\mathrm{CuCO}_{3}$ (cf. Engel and Maynard 1989). Blank $\mathrm{CO}_{2}$ was manometrically quantified and analyzed by stable isotope ratio mass spectrometry. The carbon contents of our untreated iron and manganese reagents were also determined using a commercial dynamic-flow furnace and coulometer (UIC, Models CM5120 and CM5012). Results of chemical and isotopic measurements on reagents and other potential sources of carbon blanks are displayed in Table 3.

TABLE 3. Potential Laboratory Sources of Blank Carbon and Observed Compositions

\begin{tabular}{llc}
\hline Potential sources of blank carbon & Carbon content & $\delta^{13} \mathrm{C}_{\mathrm{VPDB}}$ \\
\hline Torch-sealed annealed quartz tube & $0.02-0.15 \mu \mathrm{g}$ per tube $(\mathrm{n}=4)^{*}$ & -- \\
Copper (II) oxide & $0.10 \pm 0.01 \mu \mathrm{g}$ per $100 \mathrm{mg}(\mathrm{n}=10) \dagger$ & $-23.4 \pm 0.4$ \\
Manganese, not pretreated & $0.46 \pm 0.12 \mu \mathrm{g}$ per $100 \mathrm{mg}(\mathrm{n}=3) \ddagger$ & - \\
Iron, not pretreated & $1.8 \pm 0.7 \mu \mathrm{g}$ per $10 \mathrm{mg}(\mathrm{n}=7) \ddagger$ & $-28.3 \pm 0.5$ \\
Used rotary vane pump oil & -- & $-28.8 \pm 0.1$ \\
Laboratory dust & -- & $-21.7 \pm 0.1$ \\
Analyst's finger oils & -- & $-20.4 \pm 0.1$ \\
\hline
\end{tabular}

*No differences observed between use of $\mathrm{H}_{2} / \mathrm{O}_{2}$ and natural gas $/ \mathrm{O}_{2}$ torch gas mixtures.

†After combustion with $\mathrm{CuO}$, tubes were heated to $250^{\circ} \mathrm{C}$ for 2 min during gas transfer.

$\ddagger$ Two methods were employed: static closed-tube combustion/manometry and dynamic combustion/coulometry.

\section{Reduction of Standards and Chemical Analysis}

Carbon dioxide was generated by heating $20 \mathrm{mg}$ of Standard Reference Material (SRM) 4990C (new oxalic acid: $\mathrm{HOxII}$ ) with $0.5 \mathrm{~g}$ of $\mathrm{CuO}$ at $900^{\circ} \mathrm{C}$ for $6 \mathrm{~h}$, followed by two cryogenic distillations. Twelve quartz tubes, each containing $10 \mathrm{mg} \mathrm{Fe}$ and $300 \mathrm{mg} \mathrm{Mn}$, were pretreated for $3 \mathrm{~d}$. In turn, samples of $\mathrm{CO}_{2}$ were added $(10 \mu \mathrm{g}$ or $100 \mu \mathrm{g} \mathrm{C})$, and, for six of these tubes, $50 \mathrm{hPa}(50 \mathrm{mbar})$ of $\mathrm{H}_{2}$ was added before resealing (Table 4). The tubes were heated in a furnace at $500^{\circ} \mathrm{C}$ for 3,6 , or $15 \mathrm{~h}$, then cracked open into a calibrated volume connected to a partial pressure analyzer to determine the amounts and distributions of carbon in the residual gases (Verkouteren and Klouda 1992). Pertinent chemical equilibria, with equilibrium constants at $500^{\circ} \mathrm{C}$, are listed in Table 1 . After partial pressure analysis, the carbonized iron was oxidized with $\mathrm{CuO}$, and the resulting $\mathrm{CO}_{2}$ quantified and isotopically characterized as described under "Procedural Blank Characterization."

\section{Isotope Ratio Mass Spectrometry}

Isotopic compositions are expressed using the delta $(\delta)$ notation,

$$
\delta^{n}=\left[\frac{{ }^{n} R_{\text {sam }}-{ }^{n} R_{\text {std }}}{{ }^{n} R_{\text {std }}}\right] 1000,
$$

where ${ }^{\mathrm{n}} \mathrm{R}$ values are molecular or atomic isotope ratios in sample (sam) and standard (std) materials (Hut 1987). A factor of 1000 allows the $\delta$ values of the samples to be expressed as per mil (\%o) relative deviations from the specified standard. For $\mathrm{CO}_{2}$ measurements, the pertinent atomic isotope ratios are ${ }^{13} \mathrm{C} /{ }^{12} \mathrm{C}(\mathrm{n}=13)$ and ${ }^{18} \mathrm{O} /{ }^{16} \mathrm{O}(\mathrm{n}=18)$.

The accepted $\delta^{13} \mathrm{C}_{\mathrm{VPDB}}$ value for $\mathrm{CO}_{2}$ quantitatively derived from HOxII is $-17.8 \pm 0.2 \%$ (Mann 1983). The samples of $\mathrm{CO}_{2}$ were isotopically measured using the cryogenic microvolume inlet sys- 
tem of a Finnigan MAT ${ }^{\mathrm{TM}} 252$, with automated methods employed that matched the pressures and volumes of the samples and working standard. Samples of $\mathrm{CO}_{2}$ were collected after combustion of the targets. Those from the $100 \mu \mathrm{g}$ carbon reductions were split into at least two replicates for analysis. Samples from the blank combustions and those from the $10 \mu \mathrm{g}$ carbon reductions, because of sample size, allowed only one or two measurement runs for each. In all cases, uncertainties of $\delta^{13} \mathrm{C}$ values reported in Tables $2-4$ are estimated from the typical measurement reproducibility of similarly sized replicate samples measured on separate days from a large reservoir containing a stable source of $\mathrm{CO}_{2}$. For the small blanks $(<2 \mu \mathrm{g} \mathrm{C})$, measurement uncertainty was relatively large

TABLE 4. Fe-Mn Reduction Factor Variables, and Results of Carbon Inventory Measurements for $10 \mathrm{mg}$ and $100 \mathrm{mg}$ Carbon Standards [ $\mathrm{CO}_{2}$ from SRM 4990C (HOxII)]

\begin{tabular}{|c|c|c|c|c|c|c|}
\hline Reduction (h) & 3 & & 6 & & 15 & \\
\hline Initial $\mathrm{H}_{2}(\mathrm{hPa})$ & 50 & 0 & 50 & 0 & 50 & 0 \\
\hline Sample Number & S1 & S2 & S3 & S4 & S5 & S6 \\
\hline Initial carbon $( \pm \mathrm{u})$ & $10.63 \pm 0.01$ & $10.53 \pm 0.01$ & $10.68 \pm 0.01$ & $10.87 \pm 0.01$ & $10.42 \pm 0.01$ & $10.87 \pm 0.01$ \\
\hline as $\mathrm{CH}_{4}( \pm \mathrm{u})$ & $1.0 \pm 0.2$ & $0.3 \pm 0.2$ & $1.1 \pm 0.2$ & $0.2 \pm 0.2$ & $1.4 \pm 0.2$ & $0.2 \pm 0.2$ \\
\hline as $\mathrm{CO}( \pm \mathrm{u})$ & $0.2 \pm 0.1$ & $0.0 \pm 0.1$ & $0.1 \pm 0.1$ & $0.1 \pm 0.1$ & $0.1 \pm 0.1$ & $0.1 \pm 0.1$ \\
\hline as $\mathrm{CO}_{2}( \pm \mathrm{u})$ & $0.0 \pm 0.1$ & $0.0 \pm 0.1$ & $0.0 \pm 0.1$ & $0.0 \pm 0.1$ & $0.0 \pm 0.1$ & $0.0 \pm 0.1$ \\
\hline $\begin{array}{l}\text { Graphite, } m_{\text {obs }}( \pm \mathrm{u}) \\
\delta^{13} \mathrm{C}_{\text {obs }}\left(\phi_{0}\right)( \pm \mathrm{u})\end{array}$ & $\begin{array}{l}10.39 \pm 0.01 \\
-20.24 \pm 0.10\end{array}$ & $\begin{array}{l}8.44 \pm 0.01 \\
-20.55 \pm 0.10\end{array}$ & $\begin{array}{l}14.28 \pm 0.01 \\
-21.78 \pm 0.10\end{array}$ & $\begin{array}{l}10.39 \pm 0.01 \\
-19.52 \pm 0.10\end{array}$ & $\begin{array}{l}12.33 \pm 0.01 \\
-23.14 \pm 0.10\end{array}$ & $\begin{array}{l}10.39 \pm 0.01 \\
-18.49 \pm 0.10\end{array}$ \\
\hline $\begin{array}{l}\text { Graphite, } m_{\text {corr }}\left(u_{c}\right) \\
\delta^{13} C_{\text {corr }}(\% o)\left( \pm u_{c}\right) \\
\end{array}$ & $\begin{array}{c}6.42 \pm 1.46 \\
-15.16 \pm 3.12 \\
\end{array}$ & $\begin{array}{c}6.81 \pm 0.69 \\
-18.53 \pm 1.06 \\
\end{array}$ & $\begin{array}{l}10.28 \pm 1.47 \\
-19.43 \pm 1.18 \\
\end{array}$ & \begin{tabular}{|c|}
$8.76 \pm 0.70$ \\
$-17.76 \pm 0.84$ \\
\end{tabular} & $\begin{array}{c}8.34 \pm 1.41 \\
-20.92 \pm 1.14 \\
\end{array}$ & $\begin{array}{c}8.76 \pm 0.73 \\
-16.53 \pm 1.11 \\
\end{array}$ \\
\hline Graphite yield $(\%)\left( \pm \mathrm{u}_{\mathrm{c}}\right)$ & $60.40 \pm 13.74$ & $64.8 \pm 6.6$ & $96.25 \pm 13.76$ & $80.4 \pm 6.5$ & $80.04 \pm 13.53$ & $80.4 \pm 6.4$ \\
\hline $\begin{array}{l}\text { Total carbon } \\
\text { accountable }(\%)\left( \pm \mathrm{u}_{\mathrm{c}}\right)\end{array}$ & 71.7 & \pm 6.9 & $107.5 \pm 14.0$ & $83.2 \pm 7.1$ & $94.4 \pm 13.7$ & $83.2 \pm 6.9$ \\
\hline Sample Number & S7 & S8 & S9 & S10 & S11 & S12 \\
\hline Initial carbon $( \pm \mathrm{u})$ & $100.59 \pm 0.08$ & $103.32 \pm 0.08$ & $100.75 \pm 0.08$ & $96.94 \pm 0.08$ & $103.28 \pm 0.08$ & $100.72 \pm 0.08$ \\
\hline as $\mathrm{CH}_{4}( \pm \mathrm{u})$ & $2.9 \pm 0.2$ & $0.5 \pm 0.2$ & $13.7 \pm 1.1$ & $0.7 \pm 0.2$ & $24.7 \pm 2.0$ & $4.5 \pm 0.4$ \\
\hline as $\mathrm{CO}( \pm \mathrm{u})$ & $38.0 \pm 3.0$ & $49.5 \pm 3.9$ & $13.7 \pm 1.1$ & $23.1 \pm 1.8$ & $0.3 \pm 0.1$ & $0.1 \pm 0.1$ \\
\hline as $\mathrm{CO}_{2}( \pm \mathrm{u})$ & $5.8 \pm 0.5$ & $5.7 \pm 0.5$ & $13.6 \pm 1.1$ & $11.8 \pm 1.0$ & $0.0 \pm 0.1$ & $0.0 \pm 0.1$ \\
\hline $\begin{array}{l}\text { Graphite, } m_{\text {obs }}( \pm \mathrm{u}) \\
\delta^{13} C_{\text {obs }}(\% 0)( \pm u)\end{array}$ & $\begin{array}{r}42.19 \pm 0.03 \\
-44.60 \pm 0.10\end{array}$ & $\begin{array}{r}44.79 \pm 0.03 \\
-41.32 \pm 0.10 \\
\end{array}$ & $\begin{array}{r}66.21 \pm 0.05 \\
-32.39 \pm 0.10 \\
\end{array}$ & $\begin{array}{r}66.86 \pm 0.05 \\
-31.52 \pm 0.10 \\
\end{array}$ & $\begin{array}{r}79.84 \pm 0.06 \\
-23.04 \pm 0.10 \\
\end{array}$ & $\begin{array}{r}94.12 \pm 0.08 \\
-17.98 \pm 0.10 \\
\end{array}$ \\
\hline $\begin{array}{l}\text { Graphite, } m_{\text {corr }}\left( \pm u_{c}\right) \\
\delta^{13} C_{\text {corr }}\left(\%_{00}\right)\left( \pm u_{c}\right)\end{array}$ & $\begin{array}{r}38.18 \pm 1.41 \\
-46.43 \pm 0.74 \\
\end{array}$ & $\begin{array}{r}43.16 \pm 0.70 \\
-41.80 \pm 0.27 \\
\end{array}$ & $\begin{array}{r}62.20 \pm 1.42 \\
-32.72 \pm 0.18 \\
\end{array}$ & $\begin{array}{r}65.24 \pm 0.69 \\
-31.59 \pm 0.10 \\
\end{array}$ & $\begin{array}{r}75.81 \pm 1.47 \\
-22.80 \pm 0.13 \\
\end{array}$ & $\begin{array}{r}92.51 \pm 0.67 \\
-17.79 \pm 0.12 \\
\end{array}$ \\
\hline Graphite yield $(\%)\left( \pm \mathrm{u}_{\mathrm{c}}\right)$ & $37.96 \pm 1.40$ & $41.78 \pm 0.70$ & $61.74 \pm 1.41$ & $67.27 \pm 0.69$ & $73.40 \pm 1.42$ & $91.85 \pm 0.67$ \\
\hline $\begin{array}{l}\text { Total carbon } \\
\text { accountable }(\%)\left( \pm u_{c}\right)\end{array}$ & $84.4 \pm 3.3$ & $95.7 \pm 4.0$ & $103.2 \pm 2.4$ & $104.0 \pm 2.2$ & $97.6 \pm 2.4$ & $96.4 \pm 0.8$ \\
\hline
\end{tabular}

Notes. Dimensional units are micrograms of carbon, unless noted.

Uncertainties are expressed as standard uncertainty $(u)$ or combined standard uncertainty $\left(u_{c}\right)$. The Monte Carlo method was used to propagate and estimate the uncertainties reported for $\mathrm{m}_{\text {corr }}, \delta^{13} \mathrm{C}_{\text {corr }}$, graphite yield and total carbon accountable. as $\mathrm{CH}_{4}=$ Mass of carbon as methane in residual gas after reduction period.

as $\mathrm{CO}=$ Mass of carbon as carbon monoxide in residual gas after reduction period. as $\mathrm{CO}_{2}=$ Mass of carbon as carbon dioxide in residual gas after reduction period.

Graphite, $m_{\mathrm{obs}}=$ Observed mass of deposited graphite on iron fibers, manometrically measured as $\mathrm{CO}_{2}$ after combustion. Graphite, $\mathrm{m}_{\text {corr }}=$ Mass of deposited graphite on iron fibers, manometrically measured as $\mathrm{CO}_{2}$ after combustion and corrected for blank contributions (Eq. 9).

All $\delta^{13} \mathrm{C}$ values are relative to VPDB; $\delta^{13} \mathrm{C}_{\text {cor }}$ values are corrected for blank contributions (Eqs. 9-12).

Total carbon accountable $=$ sum of carbon masses as $\mathrm{CH}_{4}, \mathrm{CO}, \mathrm{CO}_{2}$ and $\mathrm{m}_{\text {corn }}$ divided by initial carbon, as percent (\%). 
$(0.5 \%, u),{ }^{2}$ since the $\mathrm{CO}_{2}$ could not be measured using pure viscous flow through the capillaries. Our working standard was related to $\mathrm{CO}_{2}$ generated from the NBS19 limestone Reference Material (RM 8544); numerical methods for converting $\mathrm{CO}_{2}$ isotopic measurements to $\delta^{13} \mathrm{C}_{\mathrm{VPDB}}$ values were made according to international conventions (Gonfiantini 1981; Allison, Francey and Meijer 1995).

\section{Accelerator Mass Spectrometry}

Using Fe-Mn chemistry with 7-day pretreatments and non- $\mathrm{H}_{2}$ reductions, a series of AMS targets was made from SRM 4990B (old oxalic acid: HOxI), SRM 4990C and NBS-21 (graphite). Carbon masses varied from $3 \mu \mathrm{g}$ to $115 \mu \mathrm{g}$ (Table 5). The $\mathrm{Fe}-\mathrm{C}$ fibers were melted into beaded targets under helium by a $1 \mathrm{~min}$ exposure at $1600^{\circ} \mathrm{C}$ in a tube furnace. Measurements were made at the University of Arizona AMS facility; the operating protocol was normal (Donahue et al. 1997) except that the Fe-C beaded targets (about $1 \mathrm{~mm}$ diameter) were carefully centered and pressed into shallow wells in the aluminum target holders. The targets projected slightly above the flush surface of the holder, so the normal $\mathrm{Cs}^{+}$beam-to-graphite geometry was matched closely but imperfectly. Fraction of modern $\left(f_{M}\right)$ values were calculated through Equation 8 , where ${ }^{14} C_{n}$ is the number of ${ }^{14} \mathrm{C}$ counts, and ${ }^{13} \mathrm{C}_{\mathrm{s}}$ is the scaled number of ${ }^{13} \mathrm{C}$ counts for the sample (sam) and the HOxI standard (as graphite):

$$
\mathrm{f}_{\mathrm{M}}=\frac{\left[\frac{{ }^{14} \mathrm{C}_{\mathrm{n}}}{{ }^{13} \mathrm{C}_{\mathrm{s}}}\right]_{\text {sam }}}{0.95 \cdot\left[\frac{{ }^{14} \mathrm{C}_{\mathrm{n}}}{{ }^{13} \mathrm{C}_{\mathrm{s}}}\right]_{\text {HOXI }}} .
$$

Each sample was measured $c a$. ten times with a 40-min integrated exposure time to the beam.

\section{Blank Corrections of Samples}

To model the chemical and isotopic compositions (and uncertainties) of the blank used for corrections to the observed sample compositions, we utilized appropriate subsets of blank carbon data. Uncertainties in reported values of $\mathrm{m}_{\text {corr }}, \delta^{13} \mathrm{C}_{\text {corr }}$ (Table 4) and $\mathrm{f}_{\mathrm{M} \text { (corr) }}$ (Table 5) were determined by Monte Carlo methods (Hammersley and Handscomb 1964; Verkouteren and Klouda 1992) rather than standard propagation formulae in order to compensate accurately for the lognormal chemical blank distributions and to avoid artifacts that arise when blank levels are a significant fraction of the total signal (Currie 1994, 1995). The chemical mass correction was done by simple subtraction (Eq. 9), where $m$ values are the masses of carbon in the observed sample (obs), the modeled blank (blk) and the corrected sample (corr):

$$
\mathrm{m}_{\text {corr }}=\mathrm{m}_{\mathrm{obs}}-\mathrm{m}_{\mathrm{blk}} \text {. }
$$

For samples with $50 \mathrm{hPa}$ of initial hydrogen (Table 4), the two $\mathrm{H}_{2}$-present blanks (samples B16 and B19, Table 2) were used to set a lognormal distribution with central mean of $4.02 \mu \mathrm{g}$ and standard deviation of $1.43 \mu \mathrm{g} .{ }^{3}$ For samples without initial hydrogen, the 18 non- $\mathrm{H}_{2}$ chemical blanks were used (Table 2); the resulting distribution was lognormal with central mean of $1.63 \mu \mathrm{g}$ and standard deviation of $0.70 \mu \mathrm{g}$. The lowest level of variability was observed for the ten non- $\mathrm{H}_{2}$ chemical

\footnotetext{
${ }^{2}$ Expressions of uncertainty conform to ISO and NIST conventions (ISO 1993; Taylor and Kuyatt 1994). Briefly, the standard uncertainty $(u)=$ estimated standard deviation of a particular measurement.

${ }^{3}$ The "standard deviation", or shape parameter of a lognormal distribution, which aptly describes blank variability, becomes increasingly asymmetric about the central mean as that mean approaches zero.
} 
TABLE 5. Summary and Results of AMS Target Data

\begin{tabular}{lllllllll}
\hline & $\begin{array}{l}\text { Standard } \\
\text { material and }\end{array}$ & $\begin{array}{l}\text { Sample } \\
\text { mass } \\
\text { target type }\end{array}$ & $\begin{array}{l}\text { Target } \\
\text { mass }\end{array}$ & $\begin{array}{l}{ }^{12} \mathrm{C} \text { ion } \\
\text { current }\end{array}$ & $\begin{array}{l}\left.\text { Observed }{ }^{14} \mathrm{C}\right) \\
\text { abundance } \\
(\mu \mathrm{A})\end{array}$ & $\begin{array}{l}\text { Corrected }{ }^{14} \mathrm{C} C \\
\left(\mathrm{f}_{\mathrm{M}}\right)^{*}\end{array}$ & $\begin{array}{l}\text { Combined } \\
\text { standard } \\
\left(\mathrm{f}_{\mathrm{M}}\right) \dagger\end{array}$ & $\begin{array}{l}\text { uncertainty } \\
\left(\mathrm{f}_{\mathrm{M}}\right) \ddagger\end{array}$ \\
Sample & $(\mathrm{s} / \sigma) \S$ \\
\hline S13 & HOxII-Bead & 36 & 1.21 & $0.23-0.60$ & 1.233 & 1.248 & 0.025 & 0.85 \\
S14 & HOxII-Bead & 12 & 0.85 & $0.37-0.48$ & 1.239 & 1.286 & 0.046 & 0.85 \\
S15 & HOxII-Graphite & large & trace & $21-29$ & 1.357 & 1.357 & 0.010 & 2.66 \\
S16 & HOxI-Bead & 115 & 2.55 & $2.4-3.2$ & 1.042 & 1.044 & 0.009 & 0.94 \\
S17 & HOxI-Bead & 33 & 0.80 & $0.9-1.6$ & 0.963 & 0.967 & 0.017 & 0.76 \\
S18 & HOxI-Bead & 5 & 0.80 & $0.02-0.03$ & 1.051 & 1.113 & 0.145 & 0.87 \\
S19 & HOxI-Graphite & large & trace & $22-30$ & 1.053 & 1.053 & 0.006 & 2.36 \\
S20 & RM21-Bead & 93 & 2.29 & $1.8-2.8$ & 0.024 & 0.012 & 0.007 & 1.39 \\
S21 & RM21-Bead & 3 & 0.89 & $0.007-0.009$ & 0.823 & 0.81 & 0.26 & 1.04 \\
B22 & Fe-Bead & 0 & 1 & $0.002-0.004$ & 0.332 & 0.33 & 0.17 & 1.07 \\
B23 & Fe-Bead & 0 & 2 & $0.003-0.004$ & 1.085 & 1.09 & 0.23 & 0.88 \\
B24 & Al Holder\# & 0 & 0 & $0.001-0.001$ & 1.526 & 1.53 & 0.51 & 1.00 \\
B25 & Al Plug** & 0 & 0 & $0.001-0.002$ & 0.466 & 0.47 & 0.30 & 0.97 \\
\hline
\end{tabular}

${ }^{*}$ Calculated through Eq. 8

†Calculated through Eq. 13

$\ddagger$ Combined standard uncertainty $\left(u_{c}\right)=$ uncertainty in blank-corrected $f_{M}$; includes standard error for the replicated median deviation (imprecision) and uncertainties in the masses and ${ }^{14} \mathrm{C} /{ }^{13} \mathrm{C}$ of the sample and blank. Does not include possible systematic biases (e.g., material and geometry effects on sputtering fractionation). Each $\mathrm{u}_{\mathrm{c}}$ was estimated from 2000 simulations (Monte Carlo error propagation; see text).

$\S(\mathrm{s} / \sigma)=$ ratio of the replication-s to the Poisson- $\sigma$; the critical value for $(\mathrm{s} / \sigma)$ is 1.37 (9 degrees of freedom; 5\% significance level), and larger values indicate the presence of non-Poisson variance.

\#Sample B24 was an empty target holder having a shallow sample well (used for beaded targets).

**Sample B25 was an empty target holder having a drilled-through sample well with posterior plug (used for graphitic targets).

blanks pretreated for $7 \mathrm{~d}$, where the central mean was $1.44 \mu \mathrm{g}$ and the standard deviation was 0.50 $\mu \mathrm{g}$.

The $\delta^{13} \mathrm{C}$ correction was done through subtraction of weighted fractional abundances. First, ${ }^{13} \mathrm{R}$ values $\left({ }^{13} \mathrm{C} /{ }^{12} \mathrm{C}\right.$ absolute ratios) were calculated from the $\delta^{13} \mathrm{C}$ values through Equation 10 for $\mathrm{x}=$ obs and blk. The ${ }^{13} \mathrm{R}_{\text {std }}$ value in Equation 10 is the ${ }^{13} \mathrm{C} /{ }^{12} \mathrm{C}$ ratio of the working standard used to relate the differential measurements to the VPDB scale (Hut 1987):

$$
{ }^{13} R_{x}=\left(\frac{\delta^{13} C_{x}}{1000}+1\right){ }^{13} R_{s t d}
$$

Second, fractional abundances were determined through Equation 11 , where ${ }^{13} \mathrm{~F}$ values are ${ }^{13} \mathrm{C}$ fractional abundances $\left[{ }^{13} \mathrm{C} /\left({ }^{12} \mathrm{C}+{ }^{13} \mathrm{C}\right)\right]$ for $\mathrm{x}=$ obs and blk:

$$
{ }^{13} F_{x}=\frac{{ }^{13} R_{x}}{1+{ }^{13} R_{x}}
$$

The value of ${ }^{13} \mathrm{~F}_{\text {corr }}$ for the sample was then calculated using Equation 12 and was used to determine the values of $\delta^{13} \mathrm{C}_{\text {corr }}$ through Equations 10 and 11:

$$
{ }^{13} F_{\text {corr }}=\frac{{ }^{13} F_{\text {obs }}-\Phi^{13} F_{b l k}}{(1-\Phi)}
$$


The $\Phi$ term is the mass fraction of blank carbon relative to total observed carbon $\left(\Phi=\mathrm{m}_{\text {blk }} /\left[\mathrm{m}_{\text {corr }}\right.\right.$ $\left.\left.+\mathrm{m}_{\mathrm{blk}}\right]\right)$. Corrections for ${ }^{14} \mathrm{C}$ blanks were based on a limited and separate subset of blank samples (S20, S21, B22, B23: Table 5). While we would expect mass, $\delta^{13} \mathrm{C}$ and $\mathrm{f}_{\mathrm{M}}$ of the blank to be interrelated, we treated $f_{M(b l k)}$ as an independent variable, and modeled $f_{M(b l k)}$ as a lognormal distribution with central mean $f_{M}=0.8$ and standard deviation $=0.3$, a wide distribution but consistent with the available data (for further discussion, see "Isotopic Characterization of Procedural Blank"). The $f_{M(c o r r)}$ values (and uncertainties) for the samples were then calculated using Equation 13 (and Monte Carlo techniques), where $\Phi=\mathrm{m}_{\text {blk }} /\left[\mathrm{m}_{\text {corr }}+\mathrm{m}_{\text {blk }}\right], \mathrm{m}_{\text {sam }}$ was the measured mass of carbon in the sample (before reduction), and $m_{\text {blk }}$ was the mass of blank pulled randomly from a lognormal distribution with central mean of $1.44 \mu \mathrm{g}$ and standard deviation of $0.50 \mu \mathrm{g}$ :

$$
f_{M(\text { corr })}=\frac{f_{M(\text { obs })}-\Phi f_{M(b l k)}}{(1-\Phi)}
$$

\section{RESULTS AND DISCUSSION}

\section{Mass Characterization of Procedural Blank}

Scatterplots of data contained in Table 2 are illustrated in Figure 2. While the results are visually compelling, effects on carbon blank mass level and variability were also estimated using factorial screening (Box, Hunter and Hunter 1978). The average level of the blank was strongly influenced only by the pressure of hydrogen in the reduction tube. Although only two blanks were prepared with $\mathrm{H}_{2}=50 \mathrm{hPa}$, these were two of the three largest blanks observed (higher than untreated iron, Table 3). There were several possible sources for the procedural carbon blank associated with our hydrogen-assisted reductions (e.g., trace $\mathrm{CO}_{2}$ in $\mathrm{H}_{2}$ cylinder; $\mathrm{CO}_{2}$ outgassing from transfer lines), but these were not pursued. Rather, we decided to avoid the use of hydrogen in order to achieve a lower average blank and to minimize the formation of yield-reducing methane, and pursued factor effects that influenced the variability of the blank. For this purpose, pertinent response variables were derived from the variance of blank carbon levels at discrete factor levels. Pretreatment time was divided into three levels $(0-1 \mathrm{~d}, 3 \mathrm{~d}$ and $7 \mathrm{~d})$ and manganese amount was split into four levels $(0 \mathrm{mg}, 90-110 \mathrm{mg}, 170-230 \mathrm{mg}$ and $280-310 \mathrm{mg})$. The standard deviation of observed blank carbon at each of these levels was subjected to factor effect analysis. With respect to pretreatment time levels, blank variabilities significantly decreased with longer pretreatments. The hydrogenation (and removal) of blank carbon from the reagents is a plausible explanation for this observation. During combustion, untreated iron (per $10 \mathrm{mg}$ ) released $1.8 \pm 0.7 \mu \mathrm{g} \mathrm{C}$, whereas untreated manganese (per $100 \mathrm{mg}$ ) released $0.46 \pm 0.12 \mu \mathrm{g} \mathrm{C}$ (Table 3 ). Relative to the iron, manganese was an insignificant source of the observed procedural blank.

\section{Isotopic Characterization of Procedural Blank}

Stable isotopic analysis of blank carbon demonstrated that $\delta^{13} C_{\text {VPDB }}$ was dependent upon mass, suggesting at least two significant blank sources. The smallest blanks ( $<1 \mu \mathrm{g} \mathrm{C}$ per $10 \mathrm{mg}$ iron) had $\delta^{13} \mathrm{C}_{\mathrm{VPDB}}$ values of $-30 \% 0 \pm 1 \%$, designated as the "base" composition of carbon within the iron fibers. When reciprocal mass was plotted against $\delta^{13} C_{V P D B}$ (Fig. 3), the intercept $\delta^{13} C_{V P D B}$ value equaled $-27 \% 0 \pm 1 \% 0(\mathrm{u})$, designated as the "ancillary" source composition. One plausible explanation for this observed mass dependence is that the base carbon blank was associated intrinsically with the iron, while the ancillary blank was introduced during the procedure.

The ${ }^{14} \mathrm{C}$ abundances of the blank sources were investigated through AMS measurements on two target holders (B24, B25), two blank Fe beads (B22, B23) and two Fe-C beads made from $3 \mu \mathrm{g}$ (S21) 

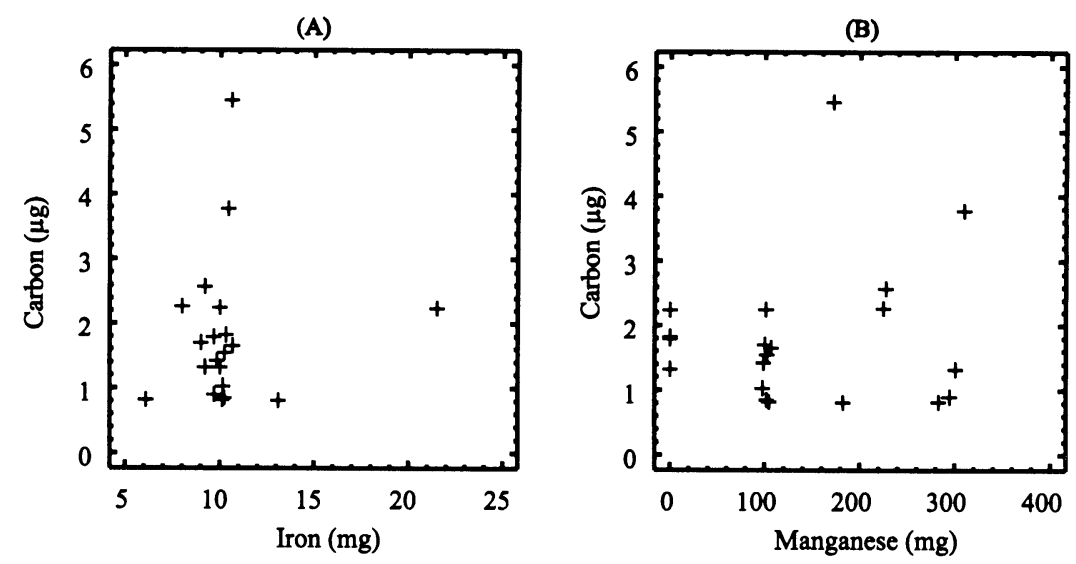

(C)

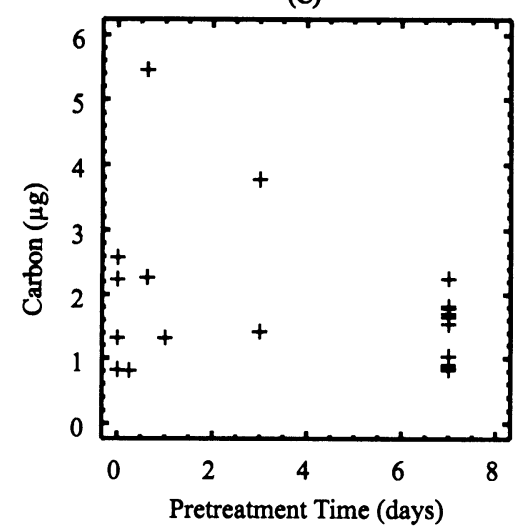

(D)

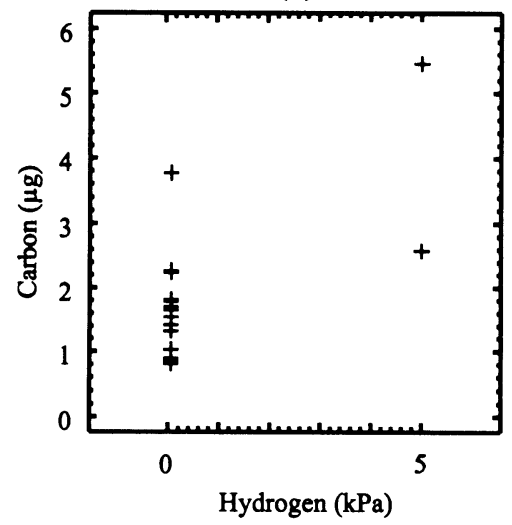

Fig. 2. Scatterplots of observed carbon blank vs. four experimental factors (plot A: iron; plot B: manganese; plot C: pretreatment time; plot D: hydrogen pressure). Data are from Table 2.

and $93 \mu \mathrm{g}$ (S20) NBS-21 carbon (Table 5). The results indicate that the procedural blank carbon was variable not only in mass and $\delta^{13} \mathrm{C}$, but also in ${ }^{14} \mathrm{C}$ signature. For all but the $93 \mu \mathrm{g} \mathrm{NBS}-21$ sample, ${ }^{14} \mathrm{C}$ count rates were very low, leading to Poisson-limited combined uncertainties of $17-51 \%$ on blank $f_{M}$ estimates. The two blank beads afforded determinations not possible with graphic targets, in that beam geometry and the target matrix was maintained without sample carbon. Measurements indicated significantly different $f_{M}$ values for the blank: variation ranged from $f_{M}=0.33 \pm 0.17$ (B22) to $f_{M}=1.09 \pm 0.23$ (B23). The results from the NBS-21 samples also provided a range of possibilities. For S20: a contemporary blank $\left(f_{M}=1.3\right)$ of $1.7 \mu \mathrm{g} \mathrm{C}\left(\right.$ with $\left.u_{c}=0.4 \mu \mathrm{g} \mathrm{C}\right)$, a modern blank $\left(f_{M}=1.0\right)$ of $2.2 \mu \mathrm{g} \mathrm{C}$ (with $\left.u_{c}=0.6 \mu g C\right)$, or a semimodern blank $\left(f_{M}=0.50\right)$ of $4.5 \mu g C$ (with $u_{c}$ $=1.2 \mu \mathrm{g} \mathrm{C}$ ). For S21: a contemporary blank of $4.7 \mu \mathrm{g} \mathrm{C} \mathrm{(with} u_{\mathrm{c}}=2.8 \mu \mathrm{g} \mathrm{C}$ ) or a modern blank of $10.8 \mu \mathrm{g} \mathrm{C}$ (with $\mathrm{u}_{\mathrm{c}}=7.8 \mu \mathrm{g} \mathrm{C}$ ). No unique ${ }^{14} \mathrm{C}$ composition for the blank consistently fit the data; rather, our measurements indicated an $\mathrm{f}_{\mathrm{M}}$ range from 0.3 to 1.3 ; hence, corrections for the procedural $\mathrm{f}_{\mathrm{M}}$ blank assumed a distribution with mean $=0.8$ and standard deviation $=0.3$.

\section{Chemical and $\delta^{13} \mathrm{C}$ Trends in $10 \mu \mathrm{g}$ Samples}

Deposited carbon reduction yields varied from $60 \%$ to $96 \%$ (Table 4, samples S1 to S6). The predominant carbonaceous gas after reduction, at all reduction time levels, was $\mathrm{CH}_{4}$. With trace $\mathrm{H}_{2}$ 


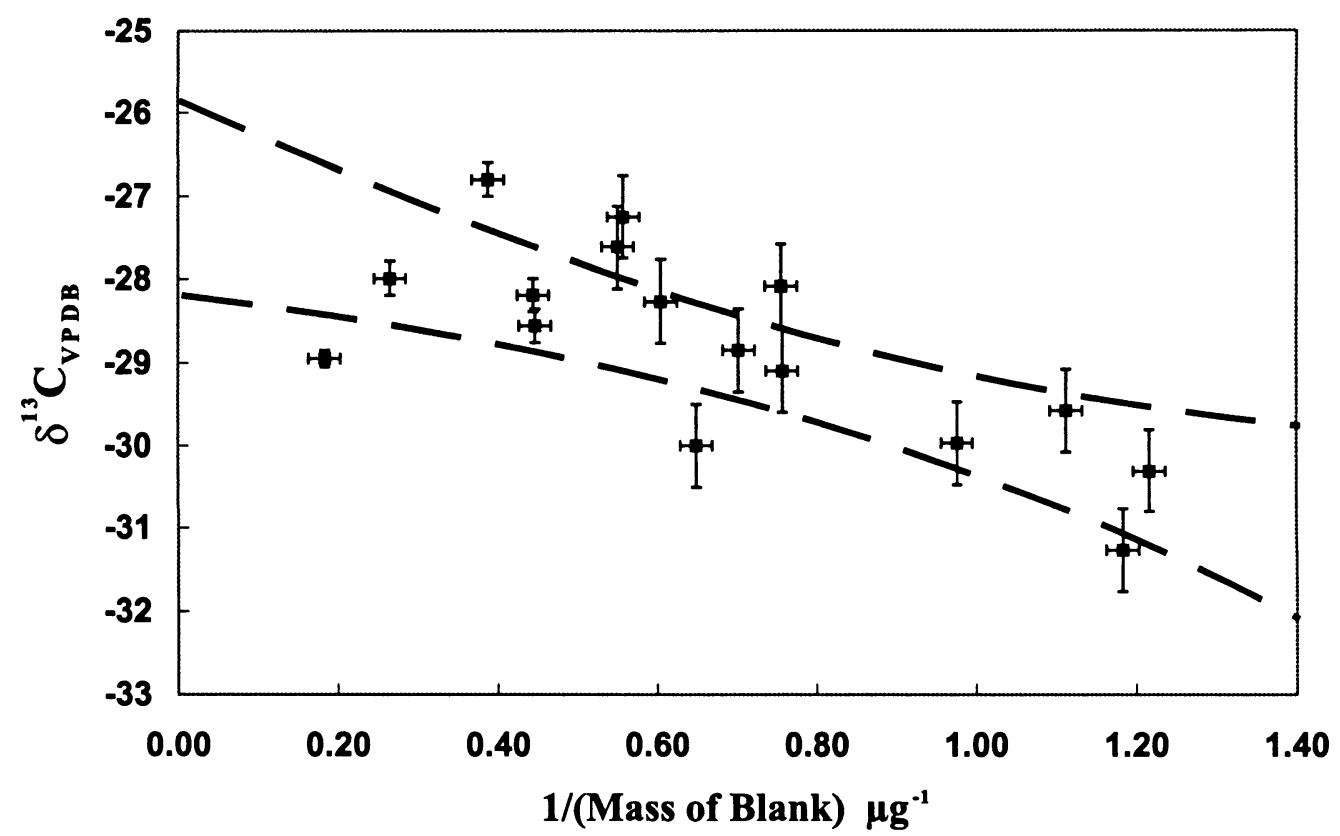

Fig. 3. Scatterplot of $\delta^{13} \mathrm{C}_{\mathrm{VPDB}} v s$. reciprocal mass of carbon from combusted iron fiber sample blanks. Data point error bars are estimated reproducibilities (u) from replicate analysis of like-sized standards, and the dashed curves are $95 \%$ confidence limits from simple linear regression. At least two sources of blank carbon are evident from the non-zero slope: the $\delta^{13} \mathrm{C}_{\mathrm{VPDB}}$ values of the "base" and "ancillary" blanks are $-30 \pm 1 \% 0$ and $-27 \pm 1 \%$, respectively (see text).

present, the amount of generated $\mathrm{CH}_{4}$ corresponded to $c a .0 .2-0.3 \mu \mathrm{g} \mathrm{C}$ equivalent and was independent of reduction time, whereas with $50 \mathrm{hPa} \mathrm{H}$ present, the amount of $\mathrm{CH}_{4}$ formed was 1.0-1.4 $\mu \mathrm{g}$ $\mathrm{C}$ with a strong dependence on reduction time. The measurements of the chemical carbon inventories for the six reduction tubes indicated that a small amount of carbon, $0-3 \mu \mathrm{g}$, was unaccountable after the reduction. This amount of carbon may have been lost during the physical removal of the manganese by dislodgment of graphite from the iron. Another loss mechanism may be the formation of graphite on the manganese, since strongly electropositive impurities of $\mathrm{Al}(0.001 \%)$ and $\mathrm{Mg}$ $(0.001 \%)$ were reported in the manganese by the supplier.

Isotopic $\left({ }^{13} \mathrm{C}\right)$ analysis of deposited graphite (Table 4, samples S1 to S6) indicated that carbon losses at the $10 \mu \mathrm{g}$ sample level did not significantly alter the isotopic compositions of the targets, and that their isotopic compositions reflected those of the original samples within $0.5 \%$ (blank-corrected $\delta^{13} \mathrm{C}$ values were within $\left.0.3 \%\right) .{ }^{14} \mathrm{C}$ analyses of $12-115 \mu \mathrm{g} \mathrm{C}$ beaded standard targets were also performed (see "AMS Analysis of Standards" for discussion).

\section{Trends in $100 \mu \mathrm{g}$ Samples}

\section{Chemical Yields}

Measurement data for $100 \mu \mathrm{g}$ samples are summarized in Table 4 (samples S7 to S12). The chemical data are also displayed in Figure 4, where we show changes in the abundances of carbonaceous species during the reduction. Dotted and dashed curves follow reductions that included $50 \mathrm{hPa} \mathrm{H}_{2}$, whereas solid curves mark reductions without hydrogen. In all cases, graphite yields were higher for non- $\mathrm{H}_{2}$ reductions; the difference in yields seems due to the production of $\mathrm{CH}_{4}$, a product of Equa- 


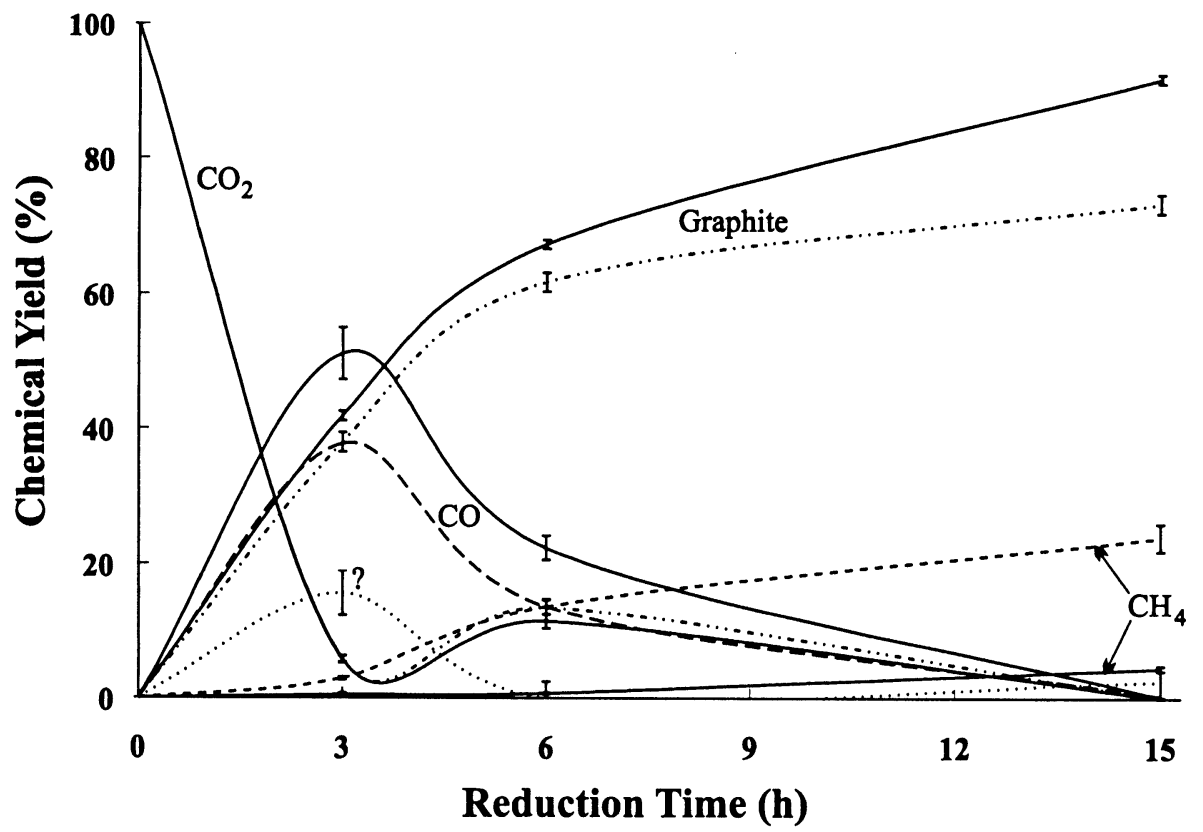

Fig. 4. Chemical yields of $\mathrm{CO}_{2}, \mathrm{CO}, \mathrm{CH}_{4}$, deposited carbon ("graphite") and missing carbon ("?") during the reduction of $100 \mu \mathrm{g}$ carbon $\left(\mathrm{as}^{\mathrm{C}} \mathrm{CO}_{2}\right.$ ) on iron with manganese. Measurements were taken at 3,6 and $15 \mathrm{~h}$ (Table 4, samples S7-S12), and data points are connected by spline curves. Error bars denote standard uncertainty (u). Solid curves identify $\mathrm{H}_{2}$-free reductions, whereas dotted and dashed curves identify reductions that used $50 \mathrm{hPa} \mathrm{H}$ (See text.)

tions 5-6 (Table 1). A small but significant amount of $\mathrm{CH}_{4}$ was detected after the non- $\mathrm{H}_{2} 15 \mathrm{~h}$ reduction (Sample S12, Table 4), expected from slow in situ hydrogen production by decomposition of trace water vapor (Eqs. 1 and 6, Table 1). Another interesting feature in Figure 4 is the behavior of $\mathrm{CO}_{2}$. The abundance of $\mathrm{CO}_{2}$ drops quickly in the first 3-4 h, but then rises slightly before slowly tailing back down. We believe the initial drop is explained by Equation 2 (Table 1), where $\mathrm{CO}_{2}$ is directly converted to $\mathrm{CO}$. After the $\mathrm{CO}$ abundance increases, graphite and $\mathrm{CO}_{2}$ are produced through Equation 3 (Table 1); this "recycled" $\mathrm{CO}_{2}$ is converted again to $\mathrm{CO}$ to drive the reduction cycle forward, where $\mathrm{CO}_{2}$ is recycled in progressively smaller quantities.

Figure 4 also records the advent and disappearance of "missing" carbon (denoted as "?"). For one sample ( $\mathrm{S} 7: 3 \mathrm{~h}$ with $\mathrm{H}_{2}$ ), the inventory of carbonaceous gases could not account for $16 \pm 3 \mu \mathrm{g}$ of carbon. This amount is similar to the difference in $\mathrm{CO}$ abundances for this sample and the analogous $\mathrm{H}_{2}$-free sample. We believe this missing carbon was associated with the manganese when the reaction was prematurely quenched, perhaps as sorbed $\mathrm{CO}$ or $\mathrm{CO}_{2}$ (Jehn et al. 1981; Deer, Howie and Zussman 1962), and was therefore not detected by our methods of inventory. The role of the hydrogen cofactor is not understood. Since the 6-and 15-h inventories accounted for all carbon, the mechanism responsible for the "missing" carbon is short-lived and such carbon eventually reenters the reduction cycle. These curves are similar in character to those obtained by McNichol et al. (1992), where $1 \mathrm{mg} \mathrm{CO} 2$ samples were reduced using either the $\mathrm{H}_{2}$ method or the $\mathrm{Fe} / \mathrm{Zn}$ method. 


\section{Isotopic Fractionation}

Figure 5 illustrates measurements and models of isotope fractionation in the target graphite as a function of reduction yield. The fractionation expected from isotopic exchange between reactants and products can be predicted through the simple Rayleigh model (Fritz and Fontes 1980),

$$
\Delta=\ln (\mathrm{f})\left[\frac{\mathrm{f}}{1-\mathrm{f}}\right](\alpha-1) 1000,
$$

where $\Delta($ as $\%)$ is the difference in isotopic compositions between a reactant and product in a closed system, $f$ is the fraction of reactant remaining, and $\alpha$ is the isotopic fractionation factor between a particular reactant and product atom at the temperature of reaction. Values for $\alpha$ are usually near unity, and for $\alpha<1$ the product is lighter than the reactant (for $\mathrm{CO}_{2} \rightarrow \mathrm{C}, \delta^{13} \mathrm{C}_{\mathrm{C}}<\delta^{13} \mathrm{C}_{\mathrm{CO}_{2}}$ ). The solid curves in Figure 5 illustrate the behavior expected if our system had followed the simple closed-system Rayleigh model-curve A uses the theoretically-derived value for the $\mathrm{CO}_{2}$-to-graphite equilibrium fractionation constant $\left(\alpha=0.9900\right.$ at $500^{\circ} \mathrm{C}$; Bottinga 1969a,b) whereas curve $\mathrm{B}$ uses the "bestfit" value ( $\alpha=0.972 \pm 0.004)$. The difference in the curves suggests the significance of kinetically controlled fractionation. One confounding influence is the recycling of the $\mathrm{CO}_{2}$ (Eqs. 2-3, Table 1), where the isotopic composition and abundance of the $\mathrm{CO}_{2}$ changes over time. Parasitic reactions

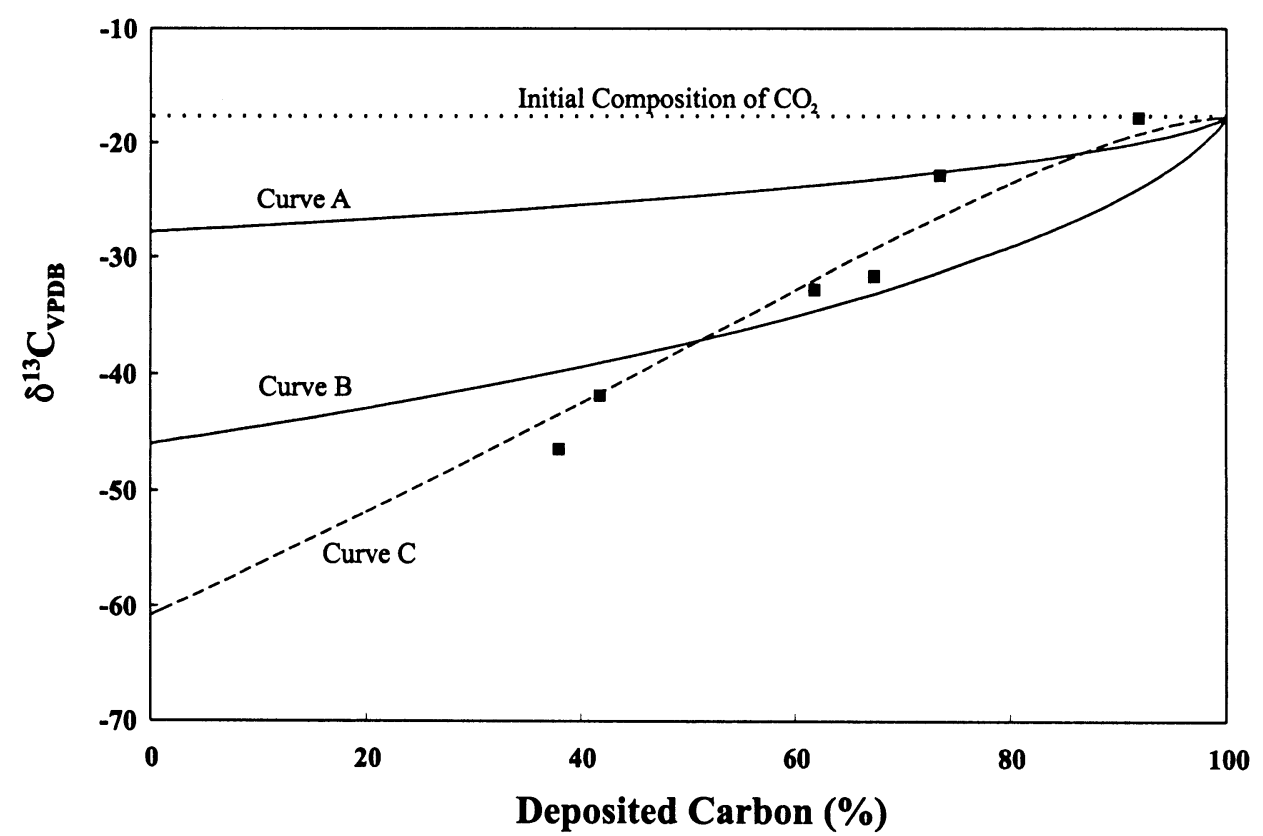

Fig. 5. Plot of ${ }^{13} \mathrm{C}$ isotopic composition of deposited carbon $v s$. percent yield of the reduction; data are from Table 4, samples S7-S12. Uncertainties for these single (nonreplicated) measurements are within the plotted sample boxes. The dotted line denotes the isotopic composition of the $\mathrm{CO}_{2}$ starting material, derived from SRM 4990C. Both solid curves depict the simple closed-system $\mathrm{CO}_{2}$-to-graphite Rayleigh fractionation model (Eq. 14); curve A uses the ${ }^{13} \mathrm{C}$ isotopic equilibrium fractionation constant $\alpha=0.990$ (Bottinga 1969a,b) and curve $\mathrm{B}$ uses $\alpha=$ 0.972 , representing the "best-fit" of the observed data to the simple model. The simple model is probably not applicable to our system due, in part, to the recycling of $\mathrm{CO}_{2}$ (Eqs. 2-3) and parasitic reactions (Eqs. 5-6). The dashed curve $C$ best fits our data, and extrapolation of the observed trend to the intercept indicates $\alpha=0.957$, a value that accords with other empirical studies (Vogel 1992; Aerts-Bijma, Meijer and van der Plicht 1997). 
(e.g., Eqs. 5-6) also may be significant. We have constructed curve $C$ in Figure 5 as a best model of the observed trend in the data. The intercept of this curve predicts the composition of the initial graphite formed and equates to $\alpha=0.957 \pm 0.004$. This fractionation constant relates well with isotopic data of comparable systems (Vogel 1992; Aerts-Bijma, Meijer and van der Plicht 1997). Additionally, the flatness of curve $\mathrm{C}$ at $90-100 \%$ yield accords with well-known observations that AMS targets are not significantly fractionated in ${ }^{14} \mathrm{C}$ abundance within this high-yield range.

\section{AMS Analysis of Standards}

AMS ${ }^{14} \mathrm{C}$ measurements were made on targets derived from HOxI, HOxII and RM21 at several carbon mass levels, and on various blank targets (Table 5). The $f_{M}$ values were corrected as described in "Blank Corrections of Samples". Precisions (combined standard uncertainties; see note $\ddagger$ in Table 5) for all but one target bead (S20) were predicated by counting statistics, which varied from $c a .1 \%$ (S16: $115 \mu \mathrm{g} \mathrm{C}$ ) to $26 \%$ (S21: $3 \mu \mathrm{g} \mathrm{C).} \mathrm{Compared} \mathrm{to} \mathrm{beaded} \mathrm{targets,} \mathrm{the} \mathrm{precisions} \mathrm{for} \mathrm{the} \mathrm{graphite}$ targets (S15, S19) and S20 (RM21: $93 \mu \mathrm{g} \mathrm{C)}$ were lower (0.6-1\%) but also exhibited non-Poisson variance, as measured by the ratio of the replication-s to the Poisson- $\sigma$ (see note $\S$ in Table 5). The reproducibilities of $f_{M}$ determinations on replicate but different-sized beaded target standards containing 12-115 $\mu \mathrm{g}$ carbon (Table 5, Samples S13, S14, S16, S17) were within 7\% and indicative of non-Poisson variance. Measurements on a smaller standard (S18, $5 \mu \mathrm{g} \mathrm{C})$ were also consistent, with a combined standard uncertainty of $c a .14 \%$. Excluding $S 18$, the average $f_{M(c o r r)}$ values determined from the HOxI and HOxII beaded targets were 5-7\% lower than the values for the graphitic targets, a bias beyond the possible effect of fractionation from incomplete chemical reduction. We attribute this bias to variations in sputtering fractionation through differences in target surface topography and geometry (Nadeau et al. 1987). Improvements in $f_{M}$ reproducibility may be realized by the matching of samples and standards in target bead size, the development of automated bead mounting procedures, and maximizing counting times afforded by the robust beads.

\section{CoNCLuSION}

Chemical and isotopic measurements indicate that the closed-tube chemical reduction system, utilizing iron and manganese metals, can be applied to the preparation of AMS targets containing 10$100 \mu \mathrm{g}$ of carbon. This approach provides significant improvements in the quality and time required for the preparation of small samples: 15 or more hours are needed for $100 \mu \mathrm{g}$ and $3-6 \mathrm{~h}$ for $10 \mu \mathrm{g}$ of carbon. Under these conditions, $\delta^{13} \mathrm{C}$ measurements indicate that target graphite is isotopically uncompromised. ${ }^{14} \mathrm{C}$ measurements, corrected for the procedural carbon blank, show a reproducible bias of $c a$. 5-7\% (relative) in $\mathrm{f}_{\mathrm{M}}$ determinations between graphitic and beaded standards, possibly an effect of sputtering variations through differences in target nature and geometry. System blanks from 7-day pretreated systems exhibited a lognormal mass distribution of $1.44 \mu \mathrm{g}$ carbon (central mean) with a standard deviation of $0.50 \mu \mathrm{g}$, and $\mathrm{f}_{\mathrm{M}}$ values ranging from 0.3 to 1.3 , translating to ${ }^{14} \mathrm{C}$ reproducibilities of $1-5 \%$ for samples containing $100-10 \mu \mathrm{g}$ carbon, respectively. While we expect that this system could be scaled up to the milligram level, sample sizes smaller than $10 \mu \mathrm{g}$ carbon suffer from procedural blank variabilities in mass and isotopic composition, leading to low signalto-Poisson noise ratios that preclude high-precision analysis. For example, the combined relative standard uncertainties associated with ${ }^{14} \mathrm{C}$ determinations of $5 \mu \mathrm{g}$ and $3 \mu \mathrm{g}$ samples are $15 \%$ and $28 \%$, respectively. Future improvements will require more rigorous control over procedural blank sources, size matching of standards and samples, and automated beaded target mounting procedures.

The $\delta^{13} \mathrm{C}$ measurements on the $100 \mu \mathrm{g}$ samples resulted in an empirical determination of the ${ }^{13} \mathrm{C}$ fractionation factor between $\mathrm{CO}_{2}$ and graphite at $500^{\circ} \mathrm{C}$. The "best-fit" value $(\alpha=0.972 \pm 0.004)$, 
assuming simple Rayleigh behavior, is significantly different from the theoretical equilibrium value $(\alpha=0.990)$; this difference may be due in part to a kinetic isotope effect during the CO disproportionation reaction (Eq. 3, Table 1). Furthermore, the observed trend in the isotopic data suggests that simple Rayleigh fractionation is not a valid model for the Fe-Mn system. Key measurements and full modeling will be required to ascertain the effects of $\mathrm{CO}_{2}$ recycling (Eqs. 2-3) and pertinent parasitic reactions.

\section{ACKNOWLEDGMENTS}

We gratefully thank the numerous reviewers that have contributed to this manuscript, including $\mathrm{H}$. A. J. Meijer, A. J. T. Jull and G. A. Klouda.

\section{REFERENCES}

Aerts-Bijma, A. Th., Meijer, H. A. J. and van der Plicht, J. 1997 AMS sample handling in Groningen. In Jull, A. J. T., Beck, J. W. and Burr, G. S., eds., Proceedings of the 7th International Conference on Accelerator Mass Spectrometry (AMS-7). Nuclear Instruments and Methods in Physics Research B123: 221-225.

Allison, C. E., Francey, R. J. and Meijer, H. A. J. 1995 Recommendations for the reporting of stable isotope measurements of carbon and oxygen in $\mathrm{CO}_{2}$ gas. In Reference and Intercomparison Materials for Stable Isotopes of Light Elements. IAEA-TECDOC-825. Vienna, International Atomic Energy Agency: 155-162.

Barin, I. 1993 Thermochemical Data of Pure Substances, Parts I-II. 2nd ed. New York, VCH.

Bottinga, Y. 1969a Carbon isotope fractionation between graphite, diamond and carbon dioxide. Earth and Planetary Science Letters 5: 301-307.

1969b Calculated fractionation factors for carbon and hydrogen isotope exchange in the system calcite$\mathrm{CO}_{2}$-graphite-methane-hydrogen and water vapor. Geochimica et Cosmochimica Acta 33: 49-64.

Box, G. E. P., Hunter, W. G. and Hunter, J. S. 1978 Statistics for Experimenters. New York: John Wiley \& Sons: $653 \mathrm{p}$.

Currie, L. A. 1994 Optimal estimation of uncertainty intervals for accelerator and decay counting. Nuclear Instruments and Methods in Physics Research B92: 188-193.

(ms.) 1995 Fundamental limits to dating and isotope ratio uncertainties due to the multivariate isotopicchemical blank. Paper presented at the 209th American Chemical Society National Meeting, NUCL034, Anaheim, California, 2-6 April.

Deer, W. A., Howie, R. A. and Zussman, J. 1962 RockForming Minerals. Vol. 5. Non-Silicates. London, Longmans: $267 \mathrm{p}$.

Desai, P. D. 1987 Thermodynamic properties of manganese and molybdenum. Journal of Physical and Chemical Reference Data 16(1): 91-108.

Donahue, D. J., Beck, J. W., Biddulph, D., Burr, G. S., Courtney, C., Damon, P. E., Hatheway, A. L., Hewitt, L., Jull, A. J. T., Lange, T., Lifton, N., Maddock, R.,
McHargue, L. R., O'Malley, J. M. and Toolin, L. J. 1997 Status of the NSF-Arizona AMS laboratory. Nuclear Instruments and Methods in Physics Research B123: 51-56.

Engel, M. H. and Maynard, R. J. 1989 Preparation of organic matter for stable carbon isotope analysis by sealed tube combustion: A cautionary note. Analytical Chemistry 61, 1996-1998.

Fritz, P. and Fontes, J.-Ch. 1980 Introduction. In Fritz, P. and Fontes, J.-Ch. eds., Handbook of Environmental Isotope Geochemistry. Volume 1. The Terrestrial Environment, Amsterdam, Elsevier: 1-19.

Gonfiantini, R. 1981 The $\delta$-notation and the mass-spectrometric techniques. In Stable Isotope Hydrology: Deuterium and Oxygen-18 in the Water Cycle. IAEATECDOC-210. Vienna, International Atomic Energy Agency: 1444-1448.

Hammersley, J. M. and Handscomb, D. C. 1964 Monte Carlo Methods. New York, John Wiley \& Sons: 178 p.

Hut, G. 1987 Consultants' Group Meeting on Stable Isotope Reference Samples for Geochemical and Hydrological Investigations. Vienna, International Atomic Energy Agency: 42p.

ISO 1993 Guide to the Expression of Uncertainty in Measurement. Geneva, International Organization for Standardization: 101p.

Jehn, H., Speck, H., Fromm, E. and Hörz, G. 1981 Gases and Carbon in Metals (Thermodynamics, Kinetics, and Properties). Part 12. Group VILA Metals. Physics Data No. 5-12.

Jull, A. J. T., Donahue, D. J., Hatheway, A. L., Linick, T. W. and Toolin, L. J. 1986 Production of graphite targets by deposition from $\mathrm{CO} / \mathrm{H}_{2}$ for precision accelerator ${ }^{14} \mathrm{C}$ measurements. In Stuiver, M. and Kra, R., eds., Proceedings of the 12 th International ${ }^{14} \mathrm{C}$ Conference. Radiocarbon 28(2A): 191-197.

Kirner, D. L., Taylor, R. E. and Southon, J. R. 1995 Reduction in backgrounds of microsamples for AMS ${ }^{14} \mathrm{C}$ dating. In Cook, G. T., Harkness, D. D., Miller, B. F. and Scott, E. M., eds., Proceedings of the 15th International ${ }^{14} \mathrm{C}$ Conference. Radiocarbon 37(2): 697704. 
Kitagawa, H., Masuzawa, T., Makamura, T. and Matsumoto, E. 1993 A batch preparation method for graphite targets with low background for AMS ${ }^{14} \mathrm{C}$ measurements. Radiocarbon 35(2): 295-300.

Klinedinst, D. B., McNichol, A. P., Currie, L. A., Schneider, R. J., Klouda, G. A., von Reden, K. F., Verkouteren, R. M. and Jones, G. A. 1994 Comparative study of $\mathrm{Fe}-\mathrm{C}$ bead and graphite target performance with the National Ocean Science AMS (NOSAMS) facility recombinator ion source. Nuclear Instruments and Methods in Physics Research B92: 166-171.

Mann, W. B. 1983 An international reference material for radiocarbon dating. In Stuiver, M. and Kra, R. S., eds., Proceedings of the 11 th International ${ }^{14} \mathrm{C}$ Conference. Radiocarbon 25(2): 519-527.

McNichol, A. P., Gagnon, A. R., Jones, G. A. and Osborne, E. A. 1992 Illumination of a black box: Analysis of gas composition during graphite target preparation. In Long, A. and Kra, R. S., eds., Proceedings of the 14 th International ${ }^{14} \mathrm{C}$ Conference. Radiocarbon 34(3): 321-329.

McNichol, A. P., Gagnon, A. R., Osborne, E. A., Hutton, D. L., von Reden, K. F. and Schneider, R. J. 1995 Improvements in procedural blanks at NOSAMS: Reflections of improvements in sample preparation and accelerator operation. In Cook, G. T., Harkness, D. D., Miller, B. F. and Scott, E. M., eds., Proceedings of the 15th International ${ }^{14} \mathrm{C}$ Conference. Radiocarbon 37(2): 683-692.

Mook, W. G. 1984 Archaeological and geological interest in applying ${ }^{14} \mathrm{C}$ AMS to small samples. In Wölfli, W., Polach, H. A. and Anderson, H. H., eds., Proceedings of the 3rd International Symposium on Accelerator Mass Spectrometry. Nuclear Instruments and Methods in Physics Research 233(B5): 297-302.

Nadeau, M.-J., Kieser, W. E., Beukens, R. P. and Litherland, A. E. 1987 Quantum mechanical effects on sputter source isotope fractionation. In Gove, H. E., Litherland, A. E. and Elmore, D., eds., Proceedings of the 4rd International Symposium on Accelerator Mass Spectrometry. Nuclear Instruments and Methods in Physics Research B29: 83-86.

Olsson, R. G. and Turkdogan, E. T. 1974 Catalytic effect of iron on decomposition of carbon monoxide: II. Effect of additions of $\mathrm{H}_{2}, \mathrm{H}_{2} \mathrm{O}, \mathrm{CO}_{2}, \mathrm{SO}_{2}$ and $\mathrm{H}_{2} \mathrm{~S}$. Metallurgical Transactions 5: 21-26.

Polach, H. A. 1984 Radiocarbon targets for AMS: A review of perceptions, aims and achievements. In Wölfli, W., Polach, H. A. and Anderson, H. H., eds., Proceedings of the 3rd International Symposium on Accelerator Mass Spectrometry. Nuclear Instruments and Methods in Physics Research 233(B5): 259-264.

Sellschop, J. P. F. 1987 Progress in accelerator mass spectrometry. In Gove, H. E., Litherland, A. E. and Elmore, D., eds., Proceedings of the 4rd International Symposium on Accelerator Mass Spectrometry. $\mathrm{Nu}$ - clear Instruments and Methods in Physics Research B29: 439-445.

Slota, P. J., Jr., Jull, A. J. T., Linick, T. W. and Toolin, L. J. 1987 Preparation of small samples for ${ }^{14} \mathrm{C}$ accelerator targets by catalytic reduction of $\mathrm{CO}$. Radiocarbon 29(2): 303-306.

Slota, P. J. and Taylor, R. E. 1989 AMS ${ }^{14} \mathrm{C}$ analysis of samples from archaeological contexts: Pretreatment and target preparation. In Ericson, J. E. and Taylor, R. E., eds., University of California Accelerator Mass Spectrometry I, Proceedings of the First U.C. Conference on AMS. Institute of Geophysical and Planetary Physics, University of California, Lawrence Livermore National Laboratory. CONF-8602126: 30-43.

Taylor, B. N. and Kuyatt, C. E. 1994 Guidelines for Evaluating and Expressing the Uncertainty of NIST Measurement Results. NIST Technical Note 1297. Washington, D.C., U.S. Government Printing Office: 20 p.

Verkouteren, R. M., Klouda, G. A., Currie, L. A., Donahue, D. J., Jull, A. J. T. and Linick, T. W. 1987 Preparation of microgram samples on iron wool for radiocarbon analysis via accelerator mass spectrometry: A closed-system approach. In Gove, H. E., Litherland, A. E. and Elmore, D., eds., Proceedings of the 4th International Symposium on Accelerator Mass Spectrometry. Nuclear Instruments and Methods in Physics Research B29: 41-44.

Verkouteren, R. M. and Klouda, G. A. 1992 Factorial design techniques applied to optimization of AMS graphite target preparation. In Long, A. and Kra, R. S., eds., Proceedings of the 14 th International ${ }^{14} \mathrm{C}$ Conference. Radiocarbon 34(3): 335-343.

Vogel, J. S. 1992 Rapid production of graphite without contamination for biomedical AMS. In Long, A. and Kra, R. S., eds., Proceedings of the 14th International ${ }^{14} \mathrm{C}$ Conference. Radiocarbon 34(3): 344-350.

1995 Report of the AMS sample preparation workshop, Saturday 13 August 1994. In Cook, G. T., Harkness, D. D., Miller, B. F. and Scott, E. M., eds., Proceedings of the 15 th International ${ }^{14} \mathrm{C}$ Conference. Radiocarbon 37(2): 815-817.

Vogel, J. S., Nelson, D. E. and Southon, J. R. 1987 Contamination of small carbon samples during graphite preparation by catalytic reduction. In Hedges, R. E. M. and Hall, E. T., eds., Workshop on Techniques in Accelerator Mass Spectrometry. Oxford, ORAU: 8-13.

Vogel, J. S., Southon, J. R., Nelson, D. E. and Brown, T. A. 1984 Performance of catalytically condensed carbon for use in accelerator mass spectrometry. In Wölfli, W., Polach, H. A. and Anderson, H. H., eds., Proceedings of the 3rd International Symposium on Accelerator Mass Spectrometry. Nuclear Instruments and Methods in Physics Research 233 (B5): 289-293.

Wilson, A. T. 1992 A simple technique for converting $\mathrm{CO}_{2}$ to AMS target graphite. In Long, A. and $\mathrm{Kra}, \mathrm{R}$. S., eds., Proceedings of the 14 th International ${ }^{14} \mathrm{C}$ Conference. Radiocarbon 34(3): 318-320. 